\title{
The Review of Financial Technology Services in Indonesia
}

\author{
Amelia Oktrivina Siregar ${ }^{1}$, Dewi Trirahayu ${ }^{2}$, Achmadi $^{3}$ \\ ${ }^{1,2}$ Faculty of Economics and Business, Universitas Pancasila \\ ${ }^{3}$ Tunas Nusantara College of Economics, Jakarta \\ \{ameliaoktrivina@univpancasila.ac.id ${ }^{1}$,dewitrirahayu@univpancasila.ac.id², \\ achmadi.stietn@gmail.com $\left.{ }^{3}\right\}$
}

\begin{abstract}
Technology and digitalization are rapidly changing the way services are in the financial sector. This innovative application of digital technology for financial services (FinTech) has been used to change financial consumers and service providers and help improve communication between the two. FinTech is a combination of financial services and information technology. In this decade, Indonesia is one of the developing countries that currently has experienced an increase in economic terms, as well as in the case of the financial industry which has changed with the development of technology. The paradigm has changed and presented new challenges for regulators and market participants in balancing the potential benefits of innovation with all the risks. This certainly invites the intervention of regulators and business actors about Financial Technology to support the development of FinTech with all its innovations.
\end{abstract}

Keywords: Financial Technology; Financial Services

\section{Introduction}

Financial technology or FinTech now has become a phenomenon in financial service with information technology. This financial technology has become a system that offers practicality, ease of access, comfort and, indeed, cost efficiency and effectivity. Fintech is a new sector in the financial industry that combines technology and financial functions. The use of this technology includes serving various fields, especially to facilitate or simplify trade transactions, corporate business or interaction and services for retail consumers.

In general, Fintech can be defined as the application of technology in finance. The term Fintech itself does not refer to an institution or financial definition. However, the relationship between finance and information technology has long been established and has developed in different fields. Wilson (2017) stated that FinTech is a company that specializes in using technology to gain profits through financial services to consumers or customers. Another source explained that FinTech is a dynamic segment between financial services and the technology sector in which start-ups company and new markets through technology are provided by the traditional financial services industry (PWC, 2017). Meanwhile, Bank Indonesia (2017) defines FinTech as a phenomenon of a combination of technology and financial features that transforms or changes business models regulated through financial institutions. The same thing was stated by Kominfo (Ministry of Ccommunications and Informatics) (2017) that stated FinTech is a combination of phenomena between technology and financial features that change the business model with not many obstacles. 
Indonesia as a developing country has enormous potential in developing Financial Technology. The growth of FinTech in Indonesia has been greatly assisted because it is supported by banking and government institutions. On the other hand, for conventional consumers, the existence of business through FinTech can be considered the beginning of bankruptcy. On the contrary, the involvement of FinTech is really able to cooperate with banking institutions. This will certainly expand the financial services network for the Indonesian population, so that it will increase the number of consumers and financial inclusion from Indonesia will grow rapidly.

However, the obstacle is that the capacity of the FinTech ecosystem in Indonesia is still considered insufficient. Therefore, the Government and regulators in the field of technology and finance must adapt in relation with policy issues and adjusting rules in an effort to mitigate risk. Other challenges faced include the gap between investor's desire and FinTech's own characteristics, especially related to the project's benefits to be gained.

\section{Literature Review}

Financial Technology (Fintech) is a name that is trending along with the development of financial services driven by digital technology, but this term is not precisely defined in practice. In some references, the name Fintech has become synonymous with the company providing the underlying technology or service, and often comes with a misleading connotation that includes only new companies. Other definitions do not distinguish between the digital technology used and the financial services that implement the technology. Most definitions refer to the terms new technology and innovation in relation to digital and cellular payments. Some examples of the current Fintech definitions include:

a) "financially supported by new technology"(European Union Parliament),

b) "technological innovation in financial services" (US National Economic Council),

c) "digitally activated financial innovation" (FSB),

d) "adoption of the emergence of digital technology in the financial industry" (HKMA),

e) "various business innovation models and new technologies have the potential to change the financial services industry" (IOSCO), and

The definition used by IOSCO about "various business innovation models and emerging technologies that have the potential to change the financial services industry that explicitly recognizes the emergence of new technologies and business models, although it does not recognize the relationship between the two. The proposed categorization places the category of new financial and technological applications based on the same footing, even though it works without acknowledging, for example, data and analytic applications for insurance or the relevance of digital currencies supported by block chain technology to payments. Or does not recognize certain new technologies that can be used by financial service providers, including for example the use of biometric technology in security applications.

None of these definitions and classifications recognize all relevant digital technology applications for financial services. Specifically, the use of technology to improve the efficiency of internal processes, compliance with regulations, and communication. Therefore, it is necessary to include these applications in discussions about changes in the financial landscape.

The lack of definitions and categorization of Fintech underscores the need to develop a more comprehensive framework to help guide the problem of digitizing financial services. While a basic understanding of technology may certainly be needed, the main concern of policy 
makers and regulators will be the application of digital technology and its implications for business models, organizational processes, etc. As long as technological innovation provides increased efficiency, this will continue to continue to drive significant changes in the way financial services are and will have significant implications for financial consumers, including micro and small businesses related to service costs and security. All agree that Fintech not only involves the application of new digital technologies for service finance but also the development of business models and products that rely on this technology and more generally on digital platforms and processes.

\section{Method}

The methodology used in this study is the literature review. Literature review can be defined as a description of the theory, findings obtained from various sources used as a database/reference in solving a problem. The first stage of this research is the collection of data and previous research on FinTech globally, covering the history and implications of certain countries. Furthermore, based on these data analyzed based on FinTech in Indonesia, which includes case studies of opportunities and challenges faced by FinTech in Indonesia. The results of this analysis are expected to be used as a basis for advice for the government, financial institutions and OJK as the regulators in Indonesia.

\section{Result and Discussion}

\subsection{The Development of FinTech in Developing Countries}

According to Hong Kong (2016), the development of FinTech in developing countries is supported by several factors that are characteristic of developing countries, namely (1) the high number of millennials who use gadgets; (2) By 2030, 60\% of the world will be in Asia; (3) financial inefficiency and capital markets will create opportunities for several informal alternatives; (4) physical banking infrastructure constraints; (5) The high behavior of millennials who like meeting places; (6) Unlimited market opportunities (1.2 million people without a banking account); and (7) data protection and competition is not tight.

Conversely, the high opportunities and challenges faced are balanced. Investors feel there is a large asymmetric information in the market activity. Asia Pacific is becoming special. In addition, the higher barriers to entry into conventional banking with less flexible regulations make investors prefer investment in developing countries. Indonesia is one of the developing countries although currently the status of Indonesia by the United States has been categorized as a developed country, with a large population of course certainly has great potential in the development of the FinTech industry. The Financial Services Authority as one of the regulators in Indonesia stressed that FinTech in Indonesia has many opportunities, due to the high number of funding service gaps, financial distribution imbalances, low levels of financial inclusion, on the other hand increasing internet technology and the use of gadgets. Meanwhile, the value of Fintech transactions in Indonesia is estimated to reach USD 14.5 million or around $0.6 \%$ of the total global transaction value of USD 2.35 million (Kominfo, 2018). The Indonesian Internet Service Providers Association (APJII) released a survey of penetration and behavior of internet users in 2018. It was said that the number of internet users reached 171.17 million people over 
the past year. This figure is up 10.12\% compared to the previous year of 143.26 million people. Compared to the population of the BPS version of 264.16 million, it can be said that there are already $64.8 \%$ of Indonesia's population who have accessed the internet.

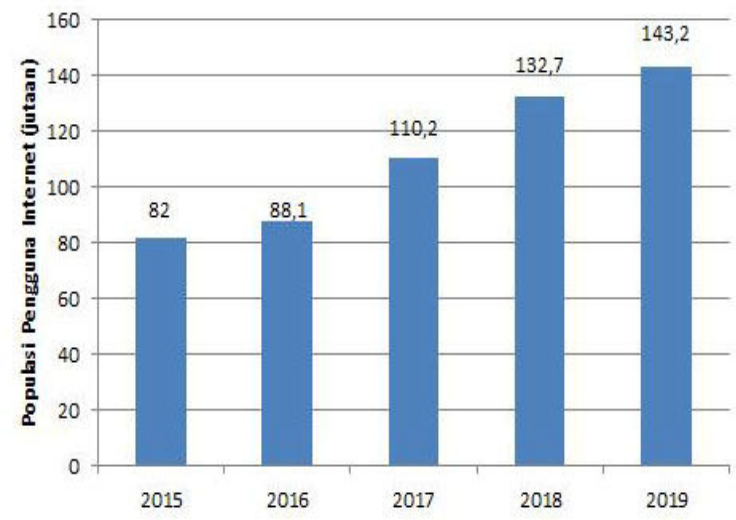

Fig. 1. Internet Users Graph (APJII, 2019)

The existence of FinTech in Indonesia must be addressed properly by the FSA as a financial services authority that functions as a regulator in Indonesia. In this case the OJK needs to take the right attitude to maintain a balance between the role of the formal and informal financial sectors, and mitigate risk through good rules without having to limit financial service sector innovation.

\subsection{FinTech Application in Financial Service}

As previously mentioned, the technological advances and new innovations have an impact on all sectors, especially financial products and services. In a number of applications, some of these services have been introduced by new entities while others are from financial institutions and existing service providers. This technology service can be classified into 8 different groups, namely: payment, planning, lending and funding, trading/investment, assurance, cybersecurity, operation and communication,

a) Payments

Payments, describe the most basic applications of digital technology for financial services. Although digital payment starts with physical instruments (such as credit cards), payment services have changed in a virtual way. Payment service innovations are broadly classified into online payments and mobile payments. Online payment can be defined as a method of payment using internet facilities, whereas mobile payments are defined as payment services connected to the mobile communication network. Therefore, online payments include online banning electronic commerce (e.g. Amazon) and payment services (e.g. PayPal).

b) Advice and planning

The increasing digital platform illustrates many opportunities for involvement in helping consumers with financial planning. Websites and online services can facilitate consumer access to financial information and training. 
c) Investment and Trading

Digital technology has also created new, more efficient ways to access and optimize trade and investment. For example, direct trading and investment platforms that will facilitate access to markets both institutional investors and retail consumers.

d) Lending and Funding

Digital technology application for granting credit and services funding business has helped new access for individuals or companies that previously had difficulty accessing the conventional credit market.

e) Insurance

Digital platform applications and technology are also transforming into the insurance field. This service has changed the way of insurance and distribution. Providers in the insurance sector can now offer easy access to insurance services through mobile device (for example: simply using a smartphone).

f) Cybersecurity

The increasing use of FinTech can increase cybersecurity risks, digital technology also presents opportunities to improve the security level of financial services.

g) Operations

For all types of financial institutions, technology has the potential to improve process effectiveness and efficiency in how it works and reduce overhead costs. This service operation process can work automatically, so the service fulfillment function can be more efficient especially if it has been facilitated by the regulation of the regulator, in this case the government.

h) Communication

New technology has changed the way communication between financial service providers and consumers/customers. Both parties, both providers and consumers have changed in terms of products and marketing. Online advertisements, for example, are often targeted by viewers, based on their browsing behavior and habits.

\subsection{The Aspects of FinTech Development on Financial Activities and Services Influences}

In general, understanding the impact and implications of the development of FinTech can be seen in one of three ways. The first way is from technology, then application technology for financial services and their potential implications. Second, in special applications, such as crowd funding, and consideration of special implications for the application. The third way, the impact of service changes, such as increasing cyber risk and these changes will affect policy.

The application of this new digital technology has a strong influence on aspects of financial activities and services. Understanding this issue can help how to start the foundation in a financial contract. Financial transactions can be conducted on a bilateral or multilateral basis, either directly between the parties or through the market, or directly through financial intermediaries. The main purpose of this financial system is to help facilitate these interactions.

a) Operating Efficiency

In the financial sphere, efficient improvements with technological innovations have affected the processes and operations that can reduce operating costs and regulatory compliance. This tends to be more flexible in changing markets, especially because it is not limited by rules (legal system).

b) Speed 
In this context, speed has two meanings, namely referring to operating speed and speed of change. Conversely, digital transactions can be executed faster than conventionally. This can also affect consumers related to time efficiency which reflects the desires of the desired transaction model. The speed of trading in the market can also have an impact on market movement and stability.

c) Ease of Access

Digitalization and financial services have clearly improved access to a variety of financial products and services for consumers or their customers, and this has great potential to help financial inclusion. This new model has become a target in terms of market segments in developing countries.

\section{Conclusion}

The development of financial technology in Indonesia has a positive influence on the economy, such as encouraging equal distribution of welfare in terms of population, helping domestic financial needs; encouraging the distribution of funding, helping funding service models, improving financial inclusion, and encouraging the ability of the MSME sector. By improving FinTech it also has social impacts, such as changes in the mindset of conventional financial institutions, looking for ways that are not flexible to be more flexible in serving consumers.

Thus, to optimize the role of Financial Technology, there should be an intervention from financial institutions and business players who are accommodated in the Association of FinTech Indonesia to work together based on information channels by utilizing data availability to strengthen the distribution channels that have been built. Second, product collaboration that has brought together consumers' needs, and this certainly requires a product that is useful for both parties.

In addition to the need for interference from the FSA as a supervisor of financial institutions, in encouraging to create rules that can protect the rights of consumers and companies without disrupting innovation

\section{References}

[1] A.S. Cui and F. Wu, Utilizing customer knowledge in innovation: Antecedents and impact of customer involvement on new product performance, Journal of the Academy of Marketing Science, 44 (2016), no. 4, 516-538. https://doi.org/10.1007/s11747-015-0433-x

[2] Bernardo Nicoletti, The Future of Fintech, Integrating Finance and Technology in Financial Services, 1st Edition. Palgrave Macmillan, Italy, 017.

[3] D.W. Arner, J.N. Barberis, R.P. Buckley, The Evolution of FinTech: A New Post-Crisis Paradigm?, SSRN Electronic Journal, 2015. https://doi.org/10.2139/ssrn.2676553

[4] Ion Micu, Alexandra Micu, Financial Technology (FinTech) and Its Implementation on The Romanian Non-Banking Capital Market, SEA Practical Application of Science, 4 (2016), 379384.

[5] J.D.Wilson, Creating Strategic Value Trhough Financial Technology, 1st Edition. Wiley Finance. Canada, 2017. https://doi.org/10.1002/9781119318682 
[6] Janos Barberis, Susanne Chisti, The Fintech Book: The Financial Technology Handbook for Investors, Entrepreneurs and Visionaries, 1st Edition, Wiley, India, 2016. https://doi.org/10.1002/9781119218906

[7] K.H. Sieljacks, Building Customer Centricity in the Banking Industry, Master Thesis Aarhus University, Aarhus, Denmark, 2014.

[8] Surat Edaran Bank Indonesia No.6/18/DPNP

[9] www.kominfo.go.id accessed on July 18th 2018. 